\title{
Analisis Pengaruh Profitabilitas, Solvabilitas, Dan Nilai Pasar Terhadap Return Saham Pada Perusahaan Go Publik Di Bursa Efek Indonesia (Studi Pada Perusahaan Jasa Sub Sektor Restoran, Hotel Dan Pariwisata)
}

\author{
Sisilia Maria Parinusa ${ }^{1}$ \\ ${ }^{1}$ Program Studi Ekonomi Pembangunan, Universitas Papua
}

Received: Januari 2020; Accepted: Februari 2020; Published: Maret 2020

\begin{abstract}
Abstrak
Rasio keuangan digunakan dalam penelitian ini untuk mengukur pengaruh profitabilitas, solvabilitas dan price to book value terhadap return saham pada restoran, hotel dan pariwisata yang terdaftar di Bursa Efek Indonesia periode 2014 - 2018. Tujuan dari penelitian ini adalah untuk memberikan temuan empiris apakah profitabilitas, solvabilitas dan price to book value berpengaruh signifikan terhadap stock return. Analisis regresi linier berganda digunakan untuk mengidentifikasi kekuatan pengaruh Return On Assets (ROA), Return On Equity (ROE), Debt to Equity Ratio (DER) dan Price to Book Value (PBV) terhadap return saham secara simultan dan parsial. Hasil penelitian ini menunjukkan bahwa secara simultan ROA, ROE, DER dan PBV berpengaruh signifikan terhadap return saham dan terdapat pengaruh positif dan signifikan return on assets terhadap stock return. Sedangkan price to book value berpengaruh negatif dan signifikan terhadap return saham pada restoran, hotel dan pariwisata yang terdaftar di BEI. Selanjutnya, return on equity dan debt to equity ratio tidak berpengaruh signifikan terhadap stock return. Di antara variabel prediktor, analisis data menunjukkan bahwa return on assets adalah variabel prediktor yang paling penting dalam model regresi ini.
\end{abstract}

Kata kunci: return saham, return on assets, return on equity, debt to equity ratio price to book value

\begin{abstract}
Financial ratios are employed in this research to measure the influence of profitability, solvency and price to book value on stock return in restaurant, hotel and tourism companies which are listed on Indonesia Stock Exchange from period 2014 - 2018. The objectives of this study was to provide empirical findings whether profitability, solvency and price to book value have a significant influence on stock return. Multiple linear regression analysis was used to identify the strength of the effect of Return On Assets (ROA), Return On Equity (ROE), Debt to Equity Ratio (DER) and Price to Book Value (PBV) on stock return simultaneously and partially. The result of this study indicates that simultaneously ROA, ROE, DER and PBV have a significant effect on stock return and there is a positive significant effect of return on assets on stock return. Whereas price to book value has a negative significant effect on stock return in restaurant, hotel and tourism companies listed on IDX. Furthermore, return on equity and debt to equity ratio have no significant impact on stock return. Among the predictor variables, the data analysis showed that return on assets is the most important predictor variables in this regression model.
\end{abstract}

Keywords: stock return, return on assets, return on equity, debt to equity ratio price to book value

How to Cite: Parinusa (2020). Analisis Pengaruh Profitabilitas, Solvabilitas, Dan Nilai Pasar Terhadap Return Saham Pada Perusahaan Go Publik Di Bursa Efek Indonesia (Studi Pada Perusahaan Jasa Sub Sektor Restoran, Hotel Dan Pariwisata) JFRES: Journal of Fiscal and Regional Economy Studies, $3(1), 22-33$

\footnotetext{
Corresponding author:

E-mail: sisilia.parinussa@gmail.com
} 


\section{PENDAHULUAN}

Investasi di bidang bisnis perhotelan dan pariwisata mengalami peningkatan dalam beberapa tahun terakhir. Tumbuhnya pusat pusat pariwisata dan bangunan hotel baru menjadi pusat bisnis yang pergerakannya signifikan. Hal ini dikarenakan adanya beberapa daerah yang difokuskan sebagai tujuan utama untuk berbisnis da nada juga daerah yang difokuskan sebagai tujuan utama untuk berbisnis dan ada juga daerah yang dijadikan sebagai tempat tujuan wisata.

Tabel 1. Nilai Investasi Sektor Pariwisata

\begin{tabular}{|c|c|}
\hline Tahun & Nilai Investasi (jutaan USD) \\
\hline 2014 & 939,20 \\
2015 & $1.048,66$ \\
2016 & $1.352,88$ \\
2017 & $1.788,05$ \\
2018 (Kwartal 1) & 433,5 \\
\hline
\end{tabular}

Sumber: Badan Koordinasi Penanaman Modal, 2018

Perusahaan jasa perhotelan dan pariwisata mengalami pertumbuhan yang sangat pesat, dimana banyak orang dari negara asing memiliki ketertarikan untuk berwisata di Indonesia. Pertumbuhan pariwisata di Indonesia mencapai 9,39\% pada tahun 2014 melebihi pertumbuhan ekonomi sebesar 5,7\%. Tingginya angka ini berpengaruh pada perhotelan. Hingga tahun 2014, nilai realisasi investasi perhotelan dan pariwisata di seluruh Indonesia mencapai US\$130,13 juta yang terdiri atas PMA sebesar US $\$ 117,24$ juta dan PMDN sebesar US $\$ 12,86$ (tempokini.com). Banyak usahawan yang memperluas jaringan usahanya dalam meningkatkan permintaan yang masuk. Untuk itu Indonesia membutuhkan banyaknya investor untuk dapat berinvestasi guna melakukan perbaikan infrastruktur dan membuat pariwisata lebih inovatif untuk mampu bersaing dengan negara-negara yang telah berkembang dalam pariwisata dan perhotelan.

Sebelum investor melakukan investasi tentunya mereka telah memperhitungkan keuntungan yang akan mereka terima dari investasi yang dilakukan. Laporan keuangan suatu perusahaan bisa dijadikan sebagai alat untuk menilai bagaimana perusahaan tersebut berjalan dan berkembang. Laporan keuangan tersaji menurut periode waktu tertentu yang telah ditetapkan sesuai dengan kesepakan bersama dan menjadi gambaran untuk menilai kinerja perusahaan.

Rasio keuangan berfungsi untuk melakukan analisis terhadap kondisi keuangan dan menilai

Share (EPS) dan Return Saham. Data kinerja manajemen perusahaan. Aktivitas perusahaan yang tertuang dalam angka-angka pada laporan keuangan akan memberikan informasi lebih apabila pengguna laporan keuangan dapat membandingkan antara komponen satu dengan komponen lainnya dalam laporan keuangan. Dari hasil pembandingan tersebut maka dapat ditarik kesimpulan posisi keuangan perusahaan pada periode tertentu. Diantara sekian banyak rasio keuangan yang dapat digunakan untuk mengukur kinerja keuangan perusahaan, ada beberapa indikator yang seringkali digunakan oleh investor untuk mendapatkan gambaran yang jelas mengenai posisi keuangan perusahaan. Adapun rasio-rasio tersebut antara lain rasio profitabilitas, solvabilitas dan price to book value. Mengingat pentingnya melihat indikator tersebut dalam menentukan posisi keuangan perusahaan sehingga penelitian ini ingin mengetahui pengaruh rasio profitabilitas, solvabilitas dan price to book value terhadap return saham baik secara bersama-sama maupun secara sendirisendiri.

Dengan melihat adanya pertumbuhan investasi di sektor pariwisata khususnya maka peneliti menilai penting untuk mengetahui lebih lanjut mengenai pengaruh rasio profitabilitas, solvabilitas dan price to book value terhadap return saham pada perusahaan-perusahaan yang bergerak di bidang jasa restoran, hotel dan pariwisata yang terdaftar di Bursa Efek Indonesia selama lima tahun terakhir yaitu tahun 2014 - 2018. Beberapa penelitian terdahulu seperti yang dilakukan oleh Aryaningsih et. al (2018) tentang pengaruh return on asset (ROA), return on equity (ROE) dan earning per share (EPS) terhadap return saham pada perusahaan consumer good (food and beverages) yang terdaftar di Bursa Efek Indonesia (BEI) periode 2013-2016. Hasil temuannya menunjukan bahwa variabel Return on Assets (ROA) secara parsial berpengaruh positif dan signifikan terhadap return saham. Sedangkan variabel Return on Equity (ROE) dan variabel Earning Per Share (EPS) secara parsial tidak berpengaruh positif dan tidak signifikan terhadap return saham. I Wayan Septiana, dkk (2017) menganalisis pengaruh return on asset dan earning per share terhadap return saham pada perusahaan sub sektor hotel, restoran dan pariwisata yang terdaftar di Bursa Efek Indonesia dalam kurun waktu pelaporan $2014-2015$. Objek penelitian adalah Return On Asset (ROA), Earning Per

dikumpulkan dengan pencatatan dokumen, dan Journal of Fiscal and Regional Economy Studies 
dianalisis dengan regresi liniear berganda. Hasil penelitian menunjukkan bahwa Return On Asset (ROA) dan Earning Per Share (EPS) secara simultan berpengaruh signifikan terhadap return Saham sebesar 71,8\%. Return On Asset (ROA) secara parsial berpengaruh positif dan signifikan terhadap return saham sebesar $68,9 \%$, dan Earning Per Share (EPS) secara parsial berpengaruh positif dan signifikan terhadap return saham sebesar $45,1 \%$.

\section{Signalling Theory}

Menurut Fahmi (2014), signaling theory adalah teori yang membahas tentang naik turunnya harga di pasar seperti harga saham, obligasi dan sebagainya, sehingga akan memberi pengaruh pada keputusan investor. Tanggapan para investor terhadap sinyal positif dan negatif adalah sangat mempengaruhi kondisi pasar, mereka akan bereaksi dengan berbagai cara dalam menanggapi sinyal tersebut, seperti memburu saham yang dijual atau melakukan tindakan dalam bentuk tidak bereaksi seperti "wait and see" atau tunggu dan lihat dulu perkembangan yang ada baru kemudian mengambil tindakan. Dan untuk dipahami keputusan wait and see bukan sesuatu yang tidak baik atau salah namun itu dilihat sebagai reaksi investor untuk menghindari timbulnya risiko yang lebih besar karena faktor pasar yang belum memberi keuntungan atau berpihak kepadanya.

\section{Pasar Modal}

Menurut Darmadji dan Fakhrudin (2011) pasar modal adalah pasar untuk berbagai instrumen keuangan jangka panjang yang diperjual belikan, baik dalam bentuk utang ataupun modal sendiri. Sedangkan dalam Widiatmojo (2012) pasar modal diartikan sebagai pasar abstrak, dimana yang diperjual belikan adalah dana-dana jangka panjang yaitu dana yang keterikatannya dalam investasi lebih dari satu tahun. Pasar modal berperan penting dalam perekonomian suatu negara. Pasar modal sebagai sarana bagi perusahaan untuk mendapatkan dana dari investor. Dana ini dapat digunakan untuk pengembangan usaha, ekspansi, penambahan modal kerja dan lain-lain. Selain itu, pasar modal menjadi sarana bagi masyarakat untuk berinvestasi pada instrument keuangan. Masayarakat dapat mengalokasikan dana yang dimilikinya sesuai dengan karakteristik keuangan dan resiko dari masing-masing instrumen yang dimilikinya. Sebagai salah satu pelaku ekonomi nasional, pasar modal memiliki fungsi intermediasi yaitu menjembatani antara pihak yang membutuhkan modal dengan pihak yang kelebihan modal Sartono (2014).

\section{Return Investasi}

Menurut Jogiyanto (2013), return merupakan hasil yang diperoleh dari investasi. Di dalam konteks investasi, return atau imbal hasil diartikan sebagai hasil keuntungan yang diperoleh investor dari kegiatan investasinya, karena itu sudah menjadi hal umum bagi investor bahwa tujuan dilakukannya investasi adalah memaksimalkan return tersebut (Halim, 2015). Pengertian lainnya menurut Tandelilin (2010) menyatakan bahwa return merupakan salah satu faktor yang memotivasi investor untuk berinvestasi. Return merupakan imbalan atas keberanian investor menanggung resiko yang dihadapinya. Return dapat dikelompokkan menjadi dua, yaitu return realisasi (realized return) dan return expektasi (expected return).

Menurut Poernamawati (2008), return saham adalah penghasilan yang diperoleh selama periode investasi per sejumlah dana yang diinvestasikan dalam bentuk saham. Return saham menurut Brigham (2011) yaitu: "Return saham atau tingkat pengembalian saham adalah selisih antara jumlah yang diterima dan jumlah yang diinvestasikan, dibagi dengan jumlah yang diinvestasikan". Sedangkan menurut Jogiyanto (2013) yaitu: "Return saham merupakan hasil yang diperoleh dari investasi"

Rumus perhitungan return saham dapat digunakan sebagai berikut (Jogiyanto, 2013):

$$
\text { Return Saham }=\frac{P_{t}-P_{t-1}}{P_{t-1}}
$$

Keterangan:

$\mathrm{P}_{\mathrm{t}}=$ Harga saham periode sekarang

$\mathrm{P}_{\mathrm{t}-1}=$ Harga saham periode sebelumnya

\section{Analisis Rasio Keuangan}

Analisis rasio keuangan adalah suatu periode analisis untuk mengetahui hubungan-hubungan dari pos-pos tertentu dalam neraca atau laporan rugi laba individual atau kombinasi kedua laporan tersebut (Munawir, 2010). Analisis rasio keuangan diartikan sebagai suatu metode atau cara menganalisis dengan menggunakan perhitungan perbandingan dari data kuantitatif yang terdapat dalam neraca ataupun laporan rugi 
laba sebuah perusahaan. Umumnya perhitungan rasio - rasio data keuangan dilakukan untuk menilai kinerja perusahaan di masa lalu, masa sekarang dan perkiraan atau berbagai kemungkinan yang terjadi pada masa yang akan datang. Analisis yang digunakan adalah dengan menggunakan rasio-rasio keuangan sesuai dengan standar yang berlaku. Menurut Habib (2008) rasio keuangan terbagi kedalam beberapa kelompok, yaitu rasio likuiditas yang terdiri dari Current Ratio (CR), Acid Test (quick) Ratio; rasio hutang terdiri dari Total Debt to Total Assets Ratio, Times Interest Earned, dan Fixed Change Coverage; rasio aktivitas yang terdiri dari Inventory Turnover, Average Collection Period, Fixed Assets Turnover, Total Assets Turnover; Rasio keuntungan terdiri dari Profit Margin on Sales, return on Assets (ROA), Return on Net Worth; Rasio Pertumbuhan yang terdiri dari pertumbuhan penjualan, pertumbuhan laba bersih, pertumbuhan laba per lembar saham, pertumbuhan harga pasar (saham) per lembar, pertumbuhan dividen; dan rasio nilai pasar yang terdiri dari price to earning ratio (PER), market to book ratio (MBR), price to book value (PBV).

\section{Rasio Profitabilitas}

Menurut Kasmir (2014), definisi rasio profitabilitas merupakan rasio untuk menilai kemampuan perusahaan dalam mencari keuntungan. Rasio ini juga memberikan ukuran tingkat efektivitas menajemen suatu perusahaan. Hal ini ditunjukkan oleh laba yang dihasilkan dari penjualan dan dan pendapatan investasi. Intinya bahwa penggunaan rasio ini menunjukkan efisiensi perusahaan.

ROA merupakan pengukuran kemampuan perusahaan secara keseluruhan dalam menghasilkan keuntungan dengan jumlah keseluruhan aktiva yang tersedia di dalam perusahaan. ROA dapat dihitung dengan rumus (Kasmir, 2014).

$$
\mathrm{ROA}=\frac{\text { Laba Bersih Sesudah Pajak }}{\text { Total Aktiva }} \times 100 \%
$$

ROA (Return of Assets) menggambarkan kinerja keuangan perusahaan dalam menghasilkan laba bersih dari aktiva yang digunakan untuk operasional perusahaan. ROA digunakan untuk mengetahui kinerja perusahaan dalam mendayagunakan jumlah assets yang dimilikinya (Susilowati dan Turyanto, 2011). ROA/ROI merupakan rasio terpenting diantar rasio-rasio profitabilitas lainnya karena dapat digunakan untuk mengukur kesehatan kinerja keuangan perusahaan (Syamsudin, 2009) karena ROA dapat menunjukkan seberapa baik suatu perusahaan mengendalikan biaya dan memanfaatkan sumber daya yang dimiliki untuk memperoleh keuntungan (Gitman, 2008).

Return Of Equity (ROE) merupakan tingkat pengembalian atas ekuitas pemilik perusahaan. Dengan kata lain ROE adalah rasio yang menunjukkan berapa persen diperoleh dari laba bersih bila diukur dari modal pemilik. Rasio ini merupakan ukuran profitabilitas dari sudut pandang pemegang saham dan merupakan alat yang paling sering digunakan investor dalam pengambilan keputusan investasi. Menurut Brigham dan Houston (2011), para pemegang saham akan melakukan investasi untuk mendapatkan pengembalian atas uang mereka dan rasio ini menunjukkan seberapa baik mereka telah melakukan hal tersebut dari kacamata akuntansi. Menurut Kasmir (2014) Return On Equity (ROE) dapat dihitung dengan rumus sebagai berikut:

$$
\mathrm{ROE}=\frac{\text { Laba Bersih Sesudah Pajak }}{\text { Modal }} \times 100 \%
$$

\section{Rasio Solvabilitas (Leverage)}

Menurut Susan Irawati (2006), leverage merupakan suatu kebijakan yang dilakukan oleh perusahaan dalam menginvestasikan dana atau memperoleh sumber dana yang disertai dengan adanya beban atau biaya tetap yang harus ditanggung perusahaan. Agus Sartono (2014) mendefinisikan leverage menunjukkan proporsi atas penggunaan utang untuk membiayai investasinya.

Perusahaan yang dalam kegiatannya banyak menggunakan utang akan meningkatkan resiko perusahaan tersebut. Hal ini tentu membuat investor mengharapkan tingkat pengembalian yang tinggi akibat resiko yang mereka hadapi. Semakin tinggi rasio hutang, semakin tinggi pula resiko perusahaan, sehingga suku bunga makin tinggi (Subramanyam dan Wild, 2014).

\section{Debt to Equity Ratio}

Rasio ini dihitung dengan membandingkan antara seluruh hutang, termasuk hutang lancar dengan seluruh ekuitas. Rasio ini berguna untuk mengetahui jumlah dana yang disediakan peminjam dengan pemilik perusahaan. Rasio ini berfungsi untuk mengetahui setiap rupiah modal sendiri yang digunakan sebagai jaminan hutang. 
Rumus perhitungan rasio ini menurut Kasmir (2014:158) sebagai berikut:

$$
\text { Debt to Equity Ratio }=\frac{\text { Total Debt }}{\text { Equity }} \times 100 \%
$$

Semakin tinggi Debt to Equity Ratio (DER) menunjukkan komposisi total utang (jangka pendek maupun jangka panjang) semakin besar dibanding dengan total modal sendiri, sehingga semakin besar beban perusahaan terhadap pihak luar (kreditur) dan semakin tidak menguntungkan, karena akan semakin besar kegagalan yang mungkin terjadi di perusahaan. Hal ini didukung oleh pendapat Van Horne (2013) yang mengatakan bahwa penting ditentukan berapa besar hutang dan modal perusahaan untuk mengetahui tingkat penggunaan hutang sebagai sumber pembiayaan perusahaan yang mencakup kewajiban jangka pendek maupun jangka panjang dalam menilai kinerja keuangan perusahaan. Selain itu, peningkatan hutang akan mempengaruhi besar kecilnya laba bersih yang tersedia bagi para pemegang saham termasuk deviden yang diterima karena kewajiban untuk membayar hutang lebih diutamakan daripada pembagian deviden.

\section{Rasio Nilai Pasar}

Menurut Irham Fahmi (2013) rasio nilai pasar adalah rasio yang menggambarkan kondisi yang terjadi di pasar. Rasio ini mampu memberikan pemahaman bagi pihak manajemen perusahaan terhadap kondisi penerapan yang akan dilaksanakan dan dampaknya di masa yang akan datang. Sedangkan menurut Abdul Halim (2012) rasio nilai pasar digunakan untuk mengukur seberapa besar kemampuan manajemen untuk mencapai nilai pasar yang melebihi pengeluaran kas.

\section{Price to Book Value (PBV)}

Price to Book Value (PBV) dalah rasio valuasi investasi yang sering digunakan oleh investor untuk membandingkan nilai pasar saham perusahaan dengan nilai bukunya. Rasio PBV ini menunjukan berapa banyak pemegang saham yang membiayai aset bersih perusahaan. Price Book to Value (PBV) dapat dihitung dengan rumus:

$$
\mathrm{PBV}=\frac{\text { Harga Pasar Saham }}{\text { Nilai Buku Per Lembar Saham }} \times 100 \%
$$

Salah satu rasio nilai pasar yang digunakan dalam analisis fundamental adalah Price to Book Value (PBV). Menurut Tryfinon (2009) Price to Book Value (PBV) adalah perhitungan atau perbandingan antara market value dengan book value suatu saham. Rasio ini berfungsi untuk melengkapi analisis book value. Jika pada analisis book value, investor hanya mengetahui kapasitas per lembar dari nilai saham, pada rasio PBV investor dapat mengetahui langsung sudah berapa kali market value suatu saham dihargai dari book value nya. Sihombing (2008) berpendapat bahwa Price to Book Value (PBV) merupakan suatu nilai yang dapat digunakan untuk membandingkan apakah suatu saham lebih mahal atau lebih murah dibandingkan dengan saham lainnya. Untuk membandingkannya, kedua perusahaan itu harus dari suatu kelompok usaha yang memiliki sifat bisnis yang sama.

\section{HIPOTESIS}

\section{Rasio Profitabilitas dan Return Saham}

Rasio ini mengukur efektivitas manajemen secara keseluruhan yang ditujukan oleh besar kecilnya tingkat keuntungan yang diperoleh dalam hubungannya dengan penjualan maupun investasi. Semakin baik rasio profitabilitas maka semakin baik menggambarkan kemampuan tingginya perolehan keuntungan perusahaan.

Signalling theory menekankan kepada pentingnya informasi yang dikeluarkan oleh perusahaan terhadap keputusan investasi pihak di luar perusahaan. Informasi merupakan unsur penting bagi investor dan pelaku bisnis karena informasi pada hakekatnya menyajikan keterangan, catatan atau gambaran baik untuk keadaan masa lalu, saat ini maupun keadaan masa yang akan datang bagi kelangsungan hidup suatu perusahaan dan bagaimana pasaran efeknya. Informasi yang lengkap, relevan, akurat dan tepat waktu sangat diperlukan oleh investor dipasar modal sebagai alat analisis untuk mengambil keputusan investasi (Fahmi, 2014).

Return on Assets (ROA) melihat sejauh mana investasi yang telah ditanamkanmampu memberikan pengembalian keuntungan sesuai dengan yang diharapkan. Dan investasi tersebut sebenarnya sama dengan aset perusahaan yang ditanamkan atau ditempatkan. Kemudian Return on Equity (ROE) disebut juga laba atas equity yaitu rasio yang mengkaji sejauh mana suatu perusahaan mempergunakan sumber daya yang dimiliki untuk mampu memberikan laba atas ekuitas. Penelitian yang dilakukan oleh Permatasari, Nurlaela dan Titisari (2019) menemukan bahwa variabel return on assets, return on equity dan earning per share 
berpengaruh secara signifikan terhadap harga saham. Kemudian Antara, Sepang dan Saerang (2014) dalam studinya menemukan bahwa return on equity berpengaruh positif dan signifikan terhadap return saham. Sehingga hipotesis pertama dan kedua yang diajukan pada penelitian ini adalah:

H1 : Return on assets berpengaruh signifikan terhadap return saham.

$\mathrm{H} 2$ : Return on equity berpengaruh signifikan terhadap return saham.

\section{Rasio Solvabilitas dan Return Saham}

Rasio Solvabilitas adalah mengukur seberapa besar perusahaan dibiayai dengan utang. Penggunaan hutang yang terlalu tinggi akan membahayakan perusahaan karena perusahaan akan masuk dalam kategori extreme leverage (hutang ekstrim) yaitu perusahaan terjebak dalam tingkat hutang yang tinggi dan sulit untuk melepaskan beban hutang tersebut. Karena itu sebaiknya perusahaan harus menyeimbangkan berapa hutang yang layak diambil dan dari mana sumber - sumber yang dapat dipakai untuk membayar hutang. Joel G. Siegel dan Jae K. Shim dalam Fahmi (2014) mendefinisikan debt to equity ratio sebagai ukuran yang dipakai dalam menganalisis laporan keuangan untuk memperlihatkan besarnya jaminan yang tersedia untuk kreditor. Tidak ada batasan berapa debt to equity ratio yang aman bagi suatu perusahaan, namun untuk konservatif biasanya debt to equity ratio yang lewat 66 persen atau 2/3 sudah dianggap berisiko. Debt to equity ratio yang semakin rendah semakin baik karena aman bagi kreditor saat likuidasi. Dalam studi yang dilakukan oleh Mussalamah dan Isa (2015) menemukan bahwa debt to equity ratio berpengaruh negatif dan signifikan terhadap harga saham artinya semakin tinggi DER maka harga saham akan menurun. Selanjutnya, Asmirantho dan Yuliawati (2015) dalam hasil penelitiannya menemukan bahwa DER tidak memiliki pengaruh yang signifikan terhadap harga saham. Dengan demikian hipotesis ketiga yang diajukan pada penelitian ini adalah:

$\mathrm{H} 3$ : Debt to equity ratio berpengaruh signifikan terhadap return saham.

\section{Rasio Nilai Pasar dan Return Saham}

Rasio nilai pasar yaitu rasio yang menggambarkan kondisi yang terjadi di pasar. Rasio ini mampu memberi pemahaman bagi pihak manajemen perusahaan terhadap kondisi penerapan yang akan dilaksanakan dan dampaknya pada masa yang akan datang. Salah satu rasio nilai pasar yang digunakan dalam analisis fundamental adalah Price to Book Value (PBV) Menurut Tryfinon (2009) Price to Book Value (PBV) adalah perhitungan atau perbandingan antara market value dengan book value suatu saham. Rasio ini berfungsi untuk melengkapi analisis book value. Jika pada analisis book value, investor hanya mengetahui kapasitas per lembar dari nilai saham, pada rasio PBV investor dapat mengetahui langsung sudah berapa kali market value suatu saham dihargai dari book value nya. Sihombing (2008) berpendapat bahwa Price to Book Value (PBV) merupakan suatu nilai yang dapat digunakan untuk membandingkan apakah suatu saham lebih mahal atau lebih murah dibandingkan dengan saham lainnya. Untuk membandingkannya, kedua perusahaan itu harus dari suatu kelompok usaha yang memiliki sifat bisnis yang sama. Dian Ayu Safitri, Budi Wahono dan M Agus Salim (2017) dalam studinya tentang pengaruh price to book value (PBV), price earning ratio (PER), debt to equity ratio (DER), dan return on assets (ROA) terhadap return saham studi kasus pada perusahaan real estate dan properti yang terdaftar di BEI periode 2012 - 2015. Hasil temuannya menyatakan bahwa variabel PBV tidak berpengaruh signifikan terhadap return saham, variabel PER berpengaruh positif dan signifikan terhadap return saham, variabel DER berpengaruh negatif dan signifikan terhadap return saham, dan variabel ROA berpengaruh positif dan signifikan terhadap return saham. Secara simultan variabel PBV, PER, DER dan ROA berpengaruh signifikan terhadap variabel dependen return saham dan variabel yang berpengaruh dominan adalah ROA. Sehingga hipotesis keempat yang diajukan dalam penelitian ini adalah:

H4 : Price to book value berpengaruh signifikan terhadap return saham.

Berdasarkan landasan teori dan beberapa penelitian yang relevan maka kerangka konseptual pada penelitian ini dapat dilihat pada Gambar 1. 


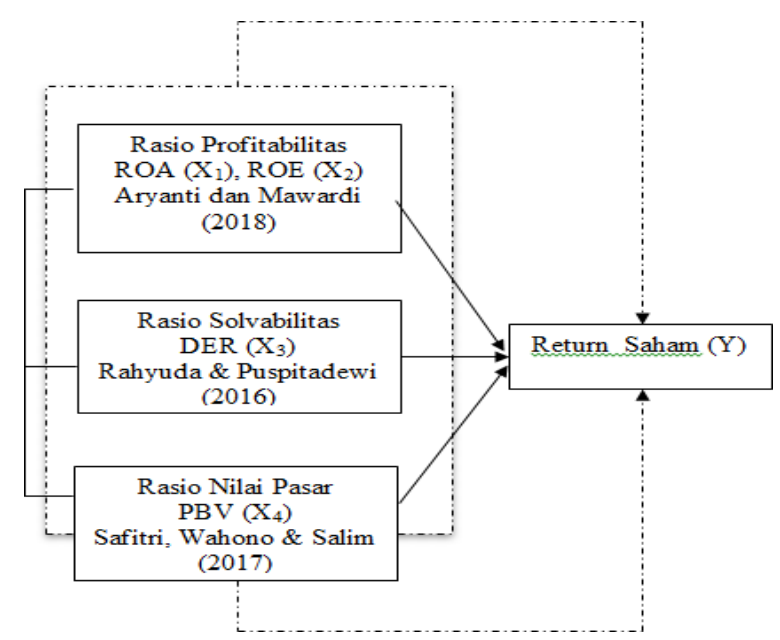

Gambar 1. Kerangka Konseptual Penelitian

\section{METODE PENELITIAN}

Penelitian ini adalah penelitian deskriptif kuantitatif, yang bermaksud untuk mengeksplorasi dan mengklarifikasi suatu fenomena atau fakta sosial, dengan jalan menjabarkan beberapa variabel yang berkaitan dengan masalah yang diteliti. Penelitian ini ingin melihat pengaruh rasio profitabilitas, rasio solvabilitas dan rasio pasar terhadap return saham berdasarkan kajian teoritis. Menurut Sugiyono (2013) metode penelitian kuantitatif dapat diartikan sebagai metode penelitian yang berlandaskan pada filsafat positivisme, digunakan untuk meneliti pada populasi atau sampel tertentu, pengumpulan data menggunakan instrument penelitian, analisis data bersifat kuantitatif / statistik dengan tujuan untuk menguji hipotesis yang telah ditetapkan. Adapun pengertian deskriptif adalah metode yang berfungsi untuk mendeskripsikan atau memberikan gambaran terhadap objek yang diteliti melalui data atau sampel yang telah terkumpul sebagaimana adanya, tanpa melakukan analisis dan membuat kesimpulan yang berlaku umum.

Dalam penelitian ini yang menjadi variabel independen adalah rasio profitabilitas, solvabilitas dan rasio pasar perusahaan. Rasio profitabilitas diukur dengan menggunakan indikator ROA dan ROE, solvabilitas menggunakan indikator DER, dan nilai pasar menggunakan indikator PBV. Sedangkan variabel dependen yang digunakan adalah return saham.

Alat analisis data yang digunakan dalam penelitian ini adalah analisis regresi linier berganda. Analisis regresi linier berganda adalah teknik statistik melalui koefisien parameter untuk mengetahui besarnya pengaruh variabel independen terhadap variabel dependen. Persamaan regresi tersebut adalah sebagai berikut:

$$
\mathbf{Y}=\boldsymbol{\beta}_{0}+\boldsymbol{\beta}_{1} \mathbf{X}_{1}+\boldsymbol{\beta}_{2} \mathbf{X}_{2}+\beta_{3} X_{3}+\beta_{4} X_{4}+e_{t}
$$

Dimana : Y = Return Saham

$\mathrm{X}_{1}=$ Variabel Independen ROA

$\mathrm{X}_{2}=$ Variabel Independen ROE

$\mathrm{X}_{3}=$ Variabel Independen DER

$\mathrm{X}_{4}=$ Variabel Independen PBV

$\alpha=$ Intercept

$\beta=$ Koefisien regresi

$\mathrm{e}_{\mathrm{t}}=$ error term

Populasi dalam penelitian ini adalah perusahaan jasa yang terdaftar di Bursa Efek Indonesia sub sektor restoran, hotel dan pariwisata. Pemilihan sampel yang akan diuji dalam penelitian ini menggunakan metode purposive sampling dengan kriteria sebagai berikut:

1. Perusahaan perhotelan yang go public dan terdaftar di Bursa Efek Indonesia periode 2014 - 2018

2. Perusahaan tidak delisting selama periode pengamatan yakni tahun $2014-2018$.

3. Perusahaan mempublikasikan laporan keuangan secara lengkap selama periode pengamatan.

Berdasarkan kriteria yang telah ditetapkan sebelumnya, maka perusahaan yang menjadi sampel dalam penelitian ini adalah 24 perusahaan sektor jasa restoran, hotel dan pariwisata yang memenuhi kriteria menerbitkan laporan keuangan yang telah diaudit selama periode pengamatan dan juga tidak melakukan merger, likuidasi dan peristiwa lain yang mengubah status perusahaan.

\section{HASIL DAN PEMBAHASAN}

\section{Uji Normalitas}

Uji normalitas adalah sebuah uji yang dilakukan dengan tujuan untuk menilai sebaran data pada sebuah kelompok data atau variabel, apakah sebaran data tersebut berdistribusi normal atau tidak. Untuk mendetesi apakah residual berdistribusi normal atau tidak, dapat dilihat melalui uji Kolmogorov Smirnov. Residual akan 
dinyatakan normal jika nilai probabilitas dari uji Kolmogorov Smirnov memiliki nilai yang lebih besar dari nilai signifikan alpha 5 persen. Pengujian asumsi normalitas menghasilkan statistik uji Kolmogorov Smirnov sebesar 0.069 dengan probabilitas sebesar 0.200. Hasil ini menunjukkan bahwa probabilitas > level of significant $(\alpha=5 \%)$. Hal ini berarti bahwa residual yang dihasilkan dinyatakan berdistribusi normal.

\section{Uji Multikolinieritas}

Uji multikolinieritas dilakukan untuk memastikan apakah di dalam sebuah model regresi ada interkorelasi atau kolinieritas antar variabel bebas. Interkorelasi adalah hubungan yang linier atau hubungan yang kuat antara satu variabel bebas atau variabel prediktor dengan variabel prediktor lainnya di dalam sebuah model regresi. Interkorelasi dapat dilihat dengan nilai koefisien korelasi antara variabel bebas, nilai Variance Inflation Factor (VIF) dan Tolerance untuk setiap variabel independen.

Data pada tabel di atas menunjukkan bahwa semua variabel independen menghasilkan nilai
VIF yang lebih kecil dari 10 dan memiliki nilai tolerance yang lebih besar dari 0.1, sehingga dapat dikatakan bahwa pada analisis regresi penelitian ini tidak mengandung gejala multikolinieritas.

\section{Uji Heteroskedastisitas}

Uji heteroskedastisitas digunakan untuk mengetahui ada atau tidaknya penyimpangan asumsi klasik heteroskedastisitas yaitu adanya ketidaksamaan varian dari residual untuk semua pengamatan pada model regresi.

Heteroskedastisitas merupakan salah satu faktor yang menyebabkan model regresi linier berganda tidak efisien dan akurat, juga mengakibatkan penggunaan metode kemungkinan maksimum dalam mengestimasi parameter (koefisien) regresi akan terganggu. Pengujian asumsi heteroskedastisitas dapat dilihat dengan Scatter Plot. Kriteris pengujian menyatakan titik - titik residual menyebar secara acak (tidak membentuk pola tertentu) maka dinyatakan asumsi heteroskedastisitas terpenuhi (Gambar 2).

Tabel 2. Hasil Pengujian Nilai Variance Inflation Factor (VIF)

\begin{tabular}{|c|c|c|}
\hline \multirow{2}{*}{ Variabel Independen } & Tolerance & Collinearity Statistics \\
\cline { 2 - 3 } & 0.890 & 1.124 \\
\hline ROA & 0.549 & 1.821 \\
\hline ROE & 0.466 & 2.145 \\
\hline DER & 0.761 & 1.314 \\
\hline PBV &
\end{tabular}

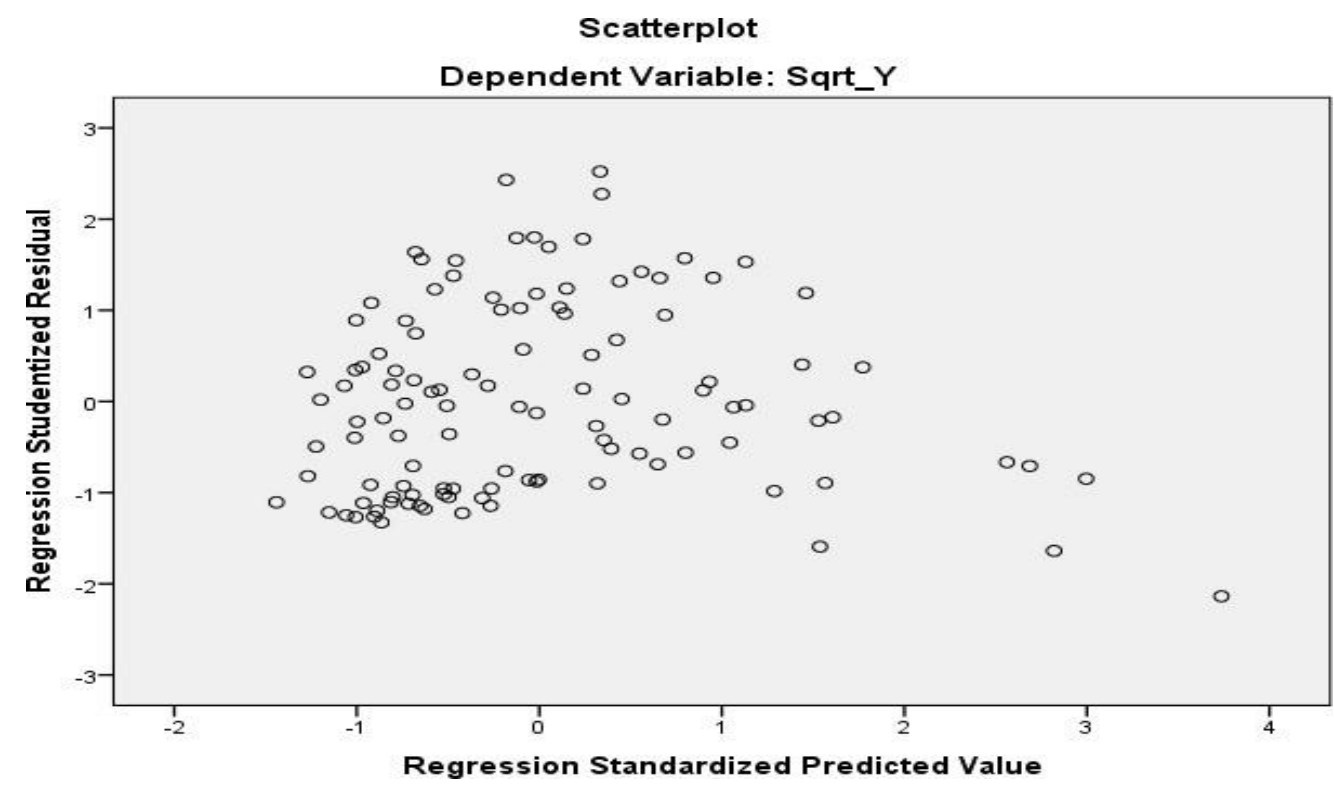

Gambar 2. Scatter Plot Pengujian Asumsi Heteroskedastisitas 


\section{Asumsi Autokorelasi}

Secara harafiah autokorelasi berarti adanya korelasi antara anggota observasi satu dengan observasi lain yang berlainan waktu. Dalam kaitannya dengan asumsi metode OLS, autokorelasi merupakan korelasi antara satu variabel gangguan dengan variabel gangguan yang lain. Sedangkan salah satu asumsi penting metode OLS berkaitan dengan variabel gangguan adalah tidak adanya hubungan antara variabel gangguan satu dengan variabel gangguan yang lain. Uji autokorelasi di dalam model regresi linier, harus dilakukan apabila data merupakan data time series atau runtut waktu. Metode yang digunakan untuk mendeteksi ada tidaknya masalah autokorelasi pada model di dalam penelitian ini adalah uji Durbin-Watson (d) ${ }^{2}$.

Tabel 3. Hasil Pengujian Autokorelasi dengan Metode Durbin Watson

\begin{tabular}{|c|c|c|c|c|c|}
\hline Model & $\mathrm{R}$ & R Square & Adjusted R Square & $\begin{array}{c}\text { Std. Error of the } \\
\text { Estimate }\end{array}$ & Durbin-Watson \\
\hline 1 & $.276^{\mathrm{a}}$ & .076 & .050 & 471.04942 & 1.864 \\
\hline
\end{tabular}

a. Predictors: (Constant), Lag_PBV, Lag_ROE, Lag_ROA

b. Dependent Variable: Lag_Return

Sumber: SPSS, (data diolah 2019).

Berdasarkan data yang terlihat pada Tabel 3 di atas, terlihat bahwa setelah dilakukan transformasi Cochrane-Orcutt, nilai statistik hitung Durbin-Watson adalah $\mathrm{d}=1.846$ sedangkan nilai kritis d pada $\alpha=5 \%$ dengan $\mathrm{n}=$ 113 dan $\mathrm{k}=4$ besarnya $\mathrm{d}_{\mathrm{L}}=1.592$ dan $\mathrm{d}_{\mathrm{U}}=$ 1.758. karena nilai d terletak di antara $d_{U}$ dan 4$\mathrm{d}_{\mathrm{U}}$ maka dapat disimpulkan bahwa model yang digunakan dalam penelitian ini tidak lagi mengandung masalah autokorelasi.

\section{Uji Regresi}

Hasil pengujian pengaruh variabel Return On Assets dan Return On Equity, variabel Debt to Equity Ratio (DER), dan Price to Book Value terhadap Return Saham dengan analisis regresi linier berganda dapat dilihat pada Tabel 4 .

Tabel 4. Hasil Estimasi Pengaruh Rasio Profitabilitas Return On Assets (ROA) dan Return On Equity (ROE), Rasio Leverage Debt to Equity Ratio (DER), dan Price to Book Value Terhadap Return Saham

\begin{tabular}{|l|c|c|c|c|}
\hline \multicolumn{1}{|c|}{ Variabel } & Koefisien & Standardized Coefficient & T statistic & Prob \\
\hline Konstanta & 21.119 & & 14.347 & 0.000 \\
\hline ROA & 65.252 & 0.344 & 2.162 & 0.033 \\
\hline ROE & 22.039 & 13.571 & 1.866 & 0.065 \\
\hline DER & 1.768 & 13.684 & 1.886 & 0.062 \\
\hline PBV & -0.002 & -0.349 & -2.798 & 0.006 \\
\hline Fstatistic $=5.591$ & \multicolumn{3}{l}{} \\
\hline R-squared $=0.170$ & \multicolumn{2}{l}{} \\
\hline
\end{tabular}

Sumber: Hasil Analisis SPSS, 2019.

Adapun persamaan regresi dari hasil estimasi analisis regresi linier berganda adalah sebagai berikut:

Return Saham $=21.119+65.252 \mathrm{ROA}+22.039$ $\mathrm{ROE}+1.768 \mathrm{DER}-0.002 \mathrm{PBV}$

\section{Pengaruh Return on Assets terhadap Return Saham}

Hasil penelitian ini menemukan bahwa Return On Assets (ROA) berpengaruh positif dan signifikan terhadap Return Saham. Hal ini berarti terjadinya peningkatan Return On Assets (ROA) sebesar 1 persen, maka akan meningkatkan nilai Return Saham sebesar
65.252\%. Semakin besar nilai ROA maka kinerja keuangan perusahaan tersebut pun semakin baik, sehingga akan menarik minat investor untuk berinvestasi di perusahaan tersebut. Tingginya minat investor akan menyebabkan harga saham meningkat sehingga hal ini akan berdampak pada meningkatnya tingkat pengembalian return saham. Hasil penelitian ini sejalan dengan hasil temuan Rahyuda dan Puspitadewi (2016) yang menunjukkan bahwa ROA berpengaruh positif dan signifikan terhadap return saham perusahaan Food and Beverages di BEI. Selain itu, Aryanti (2016) juga menemukan bahwa secara parsial ROA berpengaruh positif dan signifikan 
terhadap return saham perusahaan - perusahaan yang terdaftar di Jakarta Islamic Index (JII). Kemudian Aryaningsih (2018) dalam studinya juga menemukan bahwa secara parsial ROA berpengaruh positif dan signifikan terhadap return saham perusahaan consumer good (food and beverages) yang terdaftar di BEI periode 2013 - 2016.

\section{Pengaruh Return on Equity terhadap Return Saham}

Koefisien rasio profitabilitas ROE sebesar 22.039 mengandung arti bahwa Return On Equity (ROE) berpengaruh positif dan tidak signifikan terhadap Return Saham. Hal ini berarti terjadinya peningkatan Return On Equity (ROE) sebesar 1 persen, maka akan cenderung akan meningkatkan Return Saham sebesar $22.039 \%$, meskipun peningkatan Return Saham tersebut tidak signifikan. Semakin besar nilai rasio ROE, maka semakin besar dana yang dapat dikembalikan dari ekuitas menjadi laba. Artinya semakin besar laba bersih yang diperoleh dari modal sendiri. ROE tinggi akan menyebabkan posisi pemilik modal perusahaan semakin kuat. Hasil temuan pada penelitian ini yang menemukan bahwa ROE tidak memiliki pengaruh signifikan terhadap return saham pada perusahaan jasa sub sektor restoran, hotel dan pariwisata sejalan dengan hasil penelitian yang dilakukan oleh Sianturi (2016) yang menemukan bahwa secara parsial ROE tidak memiliki pengaruh yang signifikan terhadap return saham perusahaan - perusahaan yang tercatat pada indeks LQ 45 di BEI periode 2011 - 2014. Kemudian Aryaningsih (2018) dalam hasil penelitiannya juga menunjukkan bahwa ROE secara parsial tidak berpengaruh signifikan terhadap return saham pada perusahaan food and beverages yang tercatat di BEI.

\section{Pengaruh Debt to Equity Ratio terhadap Return Saham}

Koefisien rasio leverage Debt Equity Ratio (DER) sebesar 1.768 mengandung arti bahwa Debt Equity Ratio (DER) berpengaruh positif dan tidak signifikan terhadap Return Saham. Hal ini berarti terjadinya peningkatan Debt Equity Ratio (DER) sebesar 1 persen, maka akan cenderung akan meningkatkan Return Saham sebesar $1.768 \%$, meskipun peningkatan Return Saham tersebut tidak signifikan. Jika rasio DER meningkat beberapa investor melihat bahwa semakin tinggi DER mencerminkan tingginya tingkat hutang perusahaan sehingga meningkatkan resiko yang diterima investor sebagai akibat dari beban bunga hutang yang ditanggung perusahaan. Kondisi ini menyebabkan investor cenderung untuk tidak menanamkan modalnya pada perusahaan tersebut sehingga terjadi penurunan harga saham yang selanjutnya berdampak pada turunnya return saham perusahaan.

Akan tetapi hasil analisis pada penelitian ini menunjukkan bahwa DER memiliki hubungan positif terhadap return saham pada perusahaan sub sektor restoran, hotel dan pariwisata. Hal ini berarti bahwa pada perusahaan - perusahaan yang bergerak di bidang pariwisata investor memiliki sudut pandang yang berbeda mengenai DER. Para investor ini berpendapat bahwa hutang sangat dibutuhkan untuk menambah modal operasional prusahaan dan jika penggunaannya dioptimalkan oleh perusahaan seperti melakukan pengelolaan aset, maka perusahaan memiliki kesempatan untuk meningkatkan penjualan. Peningkatan penjualan akan berdampak pada perolehan laba perusahaan yang seakin tinggi, sehingga informasi tersebut akan mendapat respon positif dari investor yang berakibat pada permintaan saham perusahaan akan meningkat. Permintaan saham yang tinggi di pasar akan menyebabkan meningkatnya harga saham dan mengakibatkan semakin meningkatnya return saham walaupun hasilnya pengembaliannya tidak terlalu signifikan.

Hasil penelitian ini yang menunjukkan bahwa DER memiliki hubungan positif dan tidak signifikan terhadap return saham didukung oleh penelitian yang dilakukan oleh Dirgasiwi (2016) tentang pengaruh inflasi, nilai tukar mata uang, ROA dan DER terhadap return saham pada perusahaan sub sektor konstruksi bangunan yang terdaftar di BEI untuk periode 2011 - 2015. Hasil penelitiannya menunjukkan bahwa DER tidak memiliki pengaruh signifikan terhadap return saham.

\section{Pengaruh Price to Book Value terhadap Return Saham}

Koefisien rasio Price to Book Value (PBV) sebesar -0.002 mengandung arti bahwa rasio Price to Book Value (PBV) berpengaruh negatif dan signifikan terhadap Return Saham. Hal ini berarti terjadinya peningkatan rasio Price to Book Value (PBV) sebesar 1 persen, maka akan cenderung akan menurunkan Return Saham sebesar $-0.002 \%$. Kondisi ini bertentangan dengan teori yang dikemukakan sebelumnya 
karena pada penelitian ini terbukti bahwa rasio PBV yang tinggi belum tentu menunjukkan kinerja keuangan perusahaan yang sehat. Dalam penelitian ini terlihat bahwa terdapat beberapa perusahaan dengan kode emiten NASA dan MABA walaupun memiliki rasio PBV yang tinggi karena meroketnya harga saham perusahaan tersebut di pasar tetapi sebenarnya kinerja perusahaan dalam menghasilkan profit dari penjualan dan pendapapatan nilanya masih minus. Sehingga kondisi ini akan mengakibatkan capital loss atau kerugian bagi para investor. Karena peningkatan harga saham yang terjadi tidak sebanding dengan kinerja keuangan emiten - emiten tersebut. Harga saham yang tinggi di pasar lebih disebabkan karena adanya respon pasar yang positif terhadap bisnis properti dan perhotelan.

Pada kasus perusahaan jasa sub sektor restoran, hotel dan pariwisata, rasio Price to Book Value belum tentu menjadi refleksi tingginya return saham yang akan diterima atau dengan kata lain PBV tidak bisa dijadikan satu - satunya indikator dalam melakukan keputusan pembelian saham. Hal ini dikarenakan nilai PBV yang tinggi biasanya diikuti oleh dengan nilai DER yang tinggi pula. Sehingga walaupun harga saham di pasar modal tinggi bukan berarti akan memberikan return yang lebih besar karena tingginya PBV diikuti pula oleh tingginya rasio hutang (DER), sehingga sama sekali tidak menguntungkan karena laba bersih perusahaan nilainya negatif.

\section{Pengaruh Dominan}

Pengaruh variabel bebas yang paling dominan terhadap variabel terikat dapat dilihat melalui standardized coefficient yang paling besar atau berdasarkan nilai $\beta$ yang paling besar dan berpengaruh nyata. Berdasarkan hasil estimasi yang terdapat pada tabel 4 diketahui bahwa variabel yang memiliki koefisien standardisasi terbesar adalah variabel Return On Assets (ROA) sebesar 0.344 atau memiliki nilai $\beta=65.252$ dan nilai probabilitas sebesar $0.033<0.05$. Dengan demikian variabel Return On Assets (ROA) merupakan variabel yang paling berpengaruh terhadap variabel return saham.

\section{KESIMPULAN}

Berdasarkan hasil analisis maka dapat disimpulkan beberapa hal mengenai pengaruh rasio profitabilitas, solvabilitas dan rasio nilai pasar terhadap return saham, antara lain: 1) rasio profitabilitas Return On Assets (ROA) dan Return On Equity (ROE), rasio solvabilitas Debt to Equity Ratio serta rasio nilai pasar Price to Book Value secara bersama - sama berpengaruh signifikan terhadap return saham; 2) terdapat pengaruh yang positif dan signifikan rasio profitabilitas Return On Assets (ROA) terhadap return saham pada perusahaan sub sektor restoran, hotel dan pariwisata. Hal ini berarti terjadinya peningkatan ROA akan menyebabkan naiknya return saham yang diterima oleh investor; 3) rasio profitabilitas Return On Equity (ROE) berpengaruh positif dan tidak signifikan terhadap return saham pada perusahaan sub sektor restoran, hotel dan pariwisata. Hal ini berarti terjadinya peningkatan ROE akan cenderung menyebabkan naiknya return saham walaupun peningkatan tersebut tidak signifikan; 4) rasio solvabilitas Debt Equity Ratio (DER) berpengaruh positif dan tidak signifikan terhadap return saham pada perusahaan sub sektor restoran, hotel dan pariwisata. Hal ini berarti terjadinya peningkatan DER akan cenderung menyebabkan kenaikan return saham meskipun kenaikan tersebut tidak signifikan; 5) rasio nilai pasar Price to Book Value (PBV) berpengaruh negatif dan signifikan terhadap return saham pada perusahaan sub sektor restoran, hotel dan pariwisata. Hal ini berarti bahwa terjadinya peningkatan PBV akan cenderung menyebabkan menurunnya return saham yang diterima investor. Kondisi ini terjadi karena tingginya rasio PBV belum tentu mencerminkan kondisi keuangan perusahaan yang sebenarnya. Walaupun beberapa perusahaan memiliki harga saham yang tinggi di pasar, tetapi kinerja keuangannya masih bersifat minus sehingga akan menyebabkan capital loss bagi para investor; 6) diantara keempat variabel bebas yang dibahas dalam penelitian ini diketahui bahwa variabel Return On Assets (ROA) adalah variabel bebas yang paling dominan berpengaruh terhadap return saham.

\section{DAFTAR PUSTAKA}

Aryaningsih, Fathoni \& Harini. 2018. Pengaruh Return on Assets (ROA), Return on Equity (ROE), dan Earning per Share (EPS)

Aryanti, Mawardi dan Andesta. 2016. Pengaruh ROA, ROE, NPM dan CR terhadap Return Saham pada Perusahaan yang Terdaftar di Jakarta Islamic Index (JII). I - Finance, Vol.2, No.2. 
Asmirantho, E dan Yuliawati, E. 2015. Pengaruh Dividen Per Share (DPS), Dividen Payout Ratio (DPR), Price to Book Value (PBV), Debt to Equity Ratio (DER), Net Profit Margin (NPM) dan Return on Asset (ROA) Terhadap Harga Saham Perusahaan Manufaktur Sub Sektor Makanan dan Minuman dalam Kemasan yang Terdaftar di BEI. Jurnal Ilmiah Akuntansi Fakultas Ekonomi Vol.1, No,2. https://journal.unpak.ac.id/index.php/jiafe/a rticle/view/525

Dirgasiwi, D.F., Dewi, A. S., dan Gustyana, T. T. 2016. Pengaruh Inflasi, Nilai Tukar Mata Uang, Return on Assetdan Debt to Equity Ratio terhadap Return Saham Perusahaan: Studi Kasus pada Perusahaan Sub Sektor Konstruksi Bangunan yang Tercatat di BEI Periode 2011-2015. eProceeding of Management https://libraryeproceeding.telkomuniversity. ac.id/index.php/management/article/view/3 $\underline{007}$

Fahmi, Irham. 2014. Pengantar Manajemen Keuangan. Bandung: Alfabeta.

Jogiyanto, Hartono. 2013. Teori Portofolio dan Analisis Investasi. BPFE Yogyakarta, Edisi Kedelapan, Yogyakarta.

Sianturi, K., Dewi, A.S., dan Gustyana, T.T. 2016. Pengaruh Risiko Sistematis dan Return on Equity (ROE) terhadap Return Saham (Studi Kasus pada Perusahaan yang Terdaftar pada Indeks LQ45 di BursaEfek Indonesia Periode 2011 - 2014). Vol.3, No.2.

https://libraryeproceeding.telkomuniversity. ac.id/index.php/management/article/view/1 535 